\title{
Viral DNA integration and methylation of human papillomavirus type 16 in high-grade oral epithelial dysplasia and head and neck squamous cell carcinoma
}

\author{
Sujita Khanal ${ }^{1}$, Brian S. Shumway², Maryam Zahin ${ }^{3}$, Rebecca A. Redman ${ }^{3,4}$, John \\ D. Strickley ${ }^{3,4}$, Patrick J. Trainor ${ }^{3}$, Shesh N. Rai ${ }^{3}$, Shin-je Ghim ${ }^{3}$, Alfred Bennett \\ Jenson ${ }^{3}$ and Joongho Joh $^{3,4,5}$ \\ ${ }^{1}$ Division of Human Biology, Fred Hutchinson Cancer Research Center, Seattle, WA, USA \\ ${ }^{2}$ Department of Surgical and Hospital Dentistry, University of Louisville School of Dentistry, Louisville, KY, USA \\ 3 James Graham Brown Cancer Center, University of Louisville, Louisville, KY, USA \\ ${ }^{4}$ Department of Medicine, School of Medicine, University of Louisville, Louisville, KY, USA \\ ${ }^{5}$ Center for Predictive Medicine, University of Louisville, Louisville, KY, USA \\ Correspondence to: Joongho Joh, email: joongho.joh@lovisville.edu \\ Keywords: human papillomavirus (HPV); HPV integration; HPV methylation; high-grade oral epithelial dysplasia (hgOED); head \\ and neck cancer \\ Received: April 10, $2018 \quad$ Accepted: May 25, $2018 \quad$ Published: July 13, 2018 \\ Copyright: Khanal et al. This is an open-access article distributed under the terms of the Creative Commons Attribution License \\ 3.0 (CC BY 3.0), which permits unrestricted use, distribution, and reproduction in any medium, provided the original author and \\ source are credited.
}

\section{ABSTRACT}

This study evaluated the integration and methlyation of human papillomavirus type 16 (HPV16) in head and neck squamous cell carcinoma (HNSCC) and its oral precursor, high-grade oral epithelial dysplasia (hgOED). Archival samples of HPV16positive hgOED $(N=19)$ and HNSCC $(N=15)$ were evaluated, along with three HNSCC (UMSCC-1, -47 and -104) and two cervical cancer (SiHa and CaSki) cell lines. HgOED cases were stratified into three groups with increasing degrees of cytologic changes (mitosis, karyorrhexis and apoptosis). The viral load was higher and the E2/E6 ratio lower (indicating a greater tendency toward viral integration) in group 3 than in groups 1 or $2(p=0.002,0.03)$. Methylation was not observed in hgOED cases and occurred variably in only three HNSCC cases $(26.67 \%, 60.0 \%$ and $93.3 \%)$. In HNSCC cell lines, lower E7 expression correlated with higher levels of methylation. HgOED with increased cytologic change, now termed HPV-associated oral epithelial dysplasia (HPV-OED), exhibited an increased viral load and a tendency toward DNA integration, suggesting a potentially increased risk for malignant transformation. More detailed characterization and clinical follow-up of HPV-OED patients is needed to determine whether HPV-OED is a true precursor to HPV-associated HNSCC and to clarify the involvement of HPV in HNSCC carcinogenesis.

\section{INTRODUCTION}

Head and neck squamous cell carcinoma (HNSCC) originates from multiple anatomic sites, including the oral cavity (oral squamous cell carcinoma, OSCC) and the oropharynx (oropharyngeal squamous cell carcinoma, OPC). While excessive tobacco and alcohol exposure are proven risk factors contributing to many cases of HNSCC, in other cases (particularly OPC), tumorigenesis is driven by infection with one of the high-risk types of human papillomavirus (HRHPV). Of note, the response to treatment and survival are better in HPV-associated cancers than in those that lack the virus, independent of the treatment strategy $[1,2]$. While HPV is strongly 
associated with OPC, the relationship of HPV to OSCC and its premalignant precursor (high-grade oral epithelial dysplasia, hgOED) is not well understood. Our group [3] and others [4, 5] have recently reported that HRHPV is strongly associated with a certain histologic subset of hgOED, which is now designated as HPV-associated oral epithelial dysplasia (HPV-OED).

Our recent study [3] better established the histologic criteria for HPV-OED. We stratified hgOED cases based on a cytologic score determined by increasing numbers of mitotic, karyorrhectic and apoptotic cells per highpower field (hpf) (group $1[0.0$ to $<1.7]$; group 2 [1.7 to $<5.3]$; group $3[\geq 5.3]$ ). The odds of detecting HPV by PCR were 5.83 times greater in group 3 than in groups 1 and 2 combined. HRHPV was detected in $83.3 \%(10 / 12)$ of group 3 cases vs. $42.3 \%$ (11/26) of group 1 and 2 cases, and HPV16 was the type most often observed (90.5\%) for all HRHPV-positive cases. Group 3 lesions were also more likely to display diffuse p16 expression by immunohistochemistry, and the combination of the cytologic score and p16 expression was a specific predictor for HRHPV. We did not observe a difference in the clinical progression of the disease among the groups, but our long-term follow-up was limited. We concluded that cases of hgOED with greater cytologic change (group 3) are strongly associated with HPV, warranting the designation of HPV-OED. However, because HPV16 was still identified in $42.3 \%$ of the lesions in groups 1 and 2 , additional molecular study of these groups is needed to assess whether these differences determine the influence of HPV on the progression from dysplasia to malignancy.

Viral DNA integration and methylation are considered to be two major regulatory mechanisms for malignant transformation [6-9]. Persistent expression of HPV oncogenes (i.e., E6 and E7) is necessary for cancer development, and the expression of these genes is mainly regulated by viral protein $\mathrm{E} 2$. When this transcription factor binds to the early promoter p97 at specific E2binding sites (E2BSs) located within the HPV long control region (LCR), E6 and $E 7$ expression are reduced [10, 11]. Overexpression of $E 6$ and $E 7$ can be caused either by disruption of the $E 2$ gene via HPV genome integration or by inhibition of E2 protein binding to the LCR via HPV methylation [12].

Integration of HRHPV into the host genome has been well characterized in cervical cancer [13-18] and is thought to be a key factor in the development of malignancy [7]. In HNSCC, the data on integration (focused on HPV16) have been inconsistent and incomplete, so the relevance of integration to head and neck carcinogenesis has been unclear [19]. Thus, we investigated the involvement of viral integration in HNSCC by examining three HNSCC cell lines that are associated with HPV16 and have demonstrated integration $[20,21]$. The integration rates in HPV16-positive clinical samples of HNSCC have varied significantly, from $0 \%$
[22] to $100 \%[23,24]$, but most studies have reported a range of $40-80 \%$ [25]. Some of this variation may be due to the various methods of detection [25].

In the oropharyngeal area specifically, OPC has exhibited higher rates of HPV integration [19, 22-24, 26-32] than OSCC [28, 29, 31, 33, 34], but far fewer OSCC cases have been evaluated. Only two studies have investigated HPV16 integration in head and neck epithelial dysplasia; both of them evaluated dysplastic marginal tissue adjacent to existing OPC, and reported high integration rates [24, 35]. A major reason for this lack of data is the subtle presentation of OPC, which often arises in the tonsillar crypts without a clinically visible surface premalignant lesion [24, 25, 35]. While OSCC is commonly preceded by clinically visible white and/or red alterations, biologically relevant HRHPV infections (i.e., E6, E7 expression) have only been observed in approximately $6 \%$ of cases [36], making the acquisition of HPV-infected lesions a rarity. However, in our recent study [3], we identified a histologic subset of hgOED that was strongly associated with HPV16, and specimens from the same cohort were used in the present study to assess integration in oral premalignancies.

DNA methylation is another potential factor in the malignant transformation of the HPV-infected epithelium. Methylation of the HPV genome, which contains 15 CpG sites in the LCR, has been suggested as a biomarker for cervical cancer progression $[8,9]$. In the context of cervical cancer, methylation of HPV DNA prevents E2 from binding, thus releasing transcriptional repression and upregulating viral oncoproteins. It is not clear whether viral genome methylation is associated with malignancy in HNSCC in the same way that it is in cervical cancer, but an association has recently been suggested [37]. Paradoxically, one large study reported that the viral LCR was hypomethylated in oropharyngeal cancers, making it clear that more work is needed [38]. To our knowledge, apart from studies of host genome methylation, the HPV DNA methylation pattern in premalignant hgOED lesions has not been evaluated. Thus, we investigated the involvement of HPV DNA methylation in the malignant transformation of HNSCC.

To address the aforementioned research questions, we analyzed the physical state of HPV DNA (i.e., integrated or episomal) and the presence of potential DNA methylation sites in the HPV epigenome in patients with hgOED and HNSCC. Our findings have elucidated some of the complex mechanisms involved in HPV-induced HNSCC carcinogenesis.

\section{RESULTS}

\section{Viral load in HPV-positive cancer cell lines}

HPV16 DNA was detected in the UMSCC-47 and -104 cell lines, but not in UMSCC-1. Relative to the copy 
number in SiHa cells, 325 copies of HPV16 DNA were found in CaSki cells (Table 1); CaSki cells are known from previous studies [39] to have variable HPV DNA copy numbers (60-600). For both of the HPV16-positive HNSCC cell lines (UMSCC-47 and UMSCC-104), two viral copies were found (Table 1).

\section{HPV16 DNA integration frequency into cell line host genomic DNA}

In terms of integration status, $\mathrm{SiHa}$ cells exhibited an E2/E6 ratio of 0.0 , because $E 2$ was not detected, while $0.1 \mathrm{pg}$ of $E 6$ was detected per $20 \mathrm{ng}$ of total DNA (Table 1). This result indicated that both copies of HPV16 DNA in the SiHa cells were likely integrated into the chromosomal DNA via disrupted E2 sites, as reported previously [39]. HPV DNA integration after E2 disruption was further confirmed through the amplification of the $E 2$ open reading frame with nested PCR primers (Figure 1A). While small 3'- or 5'- E2 fragments were amplified, no full-length E2 was detected in SiHa cells (Table 1). CaSki cells exhibited an E2/E6 ratio of 0.12 , indicating that the majority of the HPV DNA in this cell line was mixed (Table 1). When calculated relative to that of the SiHa cell line, the E2/E6 ratio of CaSki cells indicated that 236 integrated and 39 episomal HPV16 DNA copies were present per cell. Accordingly, both full-length and small fragments of the $E 2$ open reading frame were amplified in CaSki cells (Figure 1B), confirming the presence of mixed forms of intact and disrupted E2 DNA.

HPV DNA integration was also determined through the evaluation of the $E 2 / E 6$ ratio in the UMSCC-47 and -104 cell lines. The E2/E6 ratios in these cells were 0.0 and 0.045 , respectively (Table 1), suggesting that both cell lines contained integrated HPV predominantly in disrupted E2 sites. The copy number relative to that of the $\mathrm{SiHa}$ cell line indicated that both copies of HPV16 DNA were integrated in the UMSCC-47 cell line. In UMSCC-104 cells, a small number of episomal DNA copies $(0.9 \times$ $10^{-4}$ copies) existed when the two copies of DNA were integrated into the host genome. Full-length E2 was not detected in either cell line by PCR (Figure 1B), confirming that the episomal form was either not detectable or not present in these cell lines.

\section{Transcriptional characterization related to integrated HPV DNA}

Because the disruption of the $E 2$ gene upon HPV DNA integration causes robust and constitutive expression of the viral E6 and E7 oncogenes in cervical cancer [1318], the expression profiles of the E2,E6 and E7 genes were tested in HNSCC cell lines (Table 1). Quantitative reverse-transcription (qRT)-PCR assays demonstrated that E6 and E7 mRNA levels varied considerably between the two studied HPV-positive HNSCC cell lines (Figure 2). $E 7$ expression was 150-fold higher in UMSCC-104 than in UMSCC-47 cells ( $p<0.001)$; however, E6 expression was approximately two-fold higher in the latter than in the former $(p<0.0351)$. E2 mRNA expression was analyzed with primers designed to anneal upstream of the frequent $E 2$ breakpoint, and the two cell lines exhibited similar E2 levels.

The levels of $\mathrm{p} 16^{\mathrm{INK} 4 \mathrm{a}}$ and EGFR have also been associated with HNSCC $[40,41]$, so the expression of these genes was examined in HNSCC cell lines by qRTPCR (Table 1). The expression of $p 16^{I N K 4 a}$ was similar in the HPV-positive UMSCC-47 and UMSCC-104 cell lines, and was significantly higher in these cells than in the HPV-negative UMSCC-1 cell line (by 5.4- and 4.0fold, respectively). EGFR expression was 1.4-fold higher in UMSCC-104 than in UMSCC-1 cells, but did not differ significantly different between UMSCC-47 and UMSCC-1 cells or between UMSCC-104 and UMSCC-47 cells (Figure 2).

\section{Viral load and HPV16 DNA integration rates}

In our previous study of hgOED cases stratified into three groups according to the number of karyorrhetic, apoptotic and mitotic elements per hpf, increases in these cytologic alterations correlated strongly with the presence of HRHPV (particularly HPV16) and with higher p16 expression [3]. In the current study, HPV16positive hgOED cases within each of these three cytologic groups (group $1[N=6]$, group $2[N=4]$, group 3 $[N=9])$ were evaluated for between-group differences in HPV copy number and integration status. Of note, one case in group 3 was excluded from the analysis due to repeatedly aberrant results. Significantly higher viral copy numbers were observed in group 3 than in group 1 $(p<0.001)$ or group $2(p=0.016$, Mann-Whitney test, Figure $3 \mathrm{~A})$. The HPV copy number in group 3 lesions was found to range from 1-46 copies. In contrast, all samples in groups 1 and 2 had relative viral loads of less than 0.1 , with one exception of 3.6 copies in group 2 (Table 2 ).

HPV integration status differed significantly among the hgOED groups ( $p=0.002$ for group 1 vs. group 3, Table 2, Figure 3B). The E2/E6 ratio results indicated a strong tendency toward fully or predominantly integrated virus forms in group 3 (0.04) vs. mixed forms and a trend toward episomal forms in group $2(0.41)$ and group 1 (0.76). In the 16 cases of HNSCC, variable viral loads (0.1-205 copies/cell) were found when the copy numbers were decided relative to $\mathrm{SiHa}$ (Table 2), and the median viral load did not differ significantly from that of group 3 hgOED $(p=0.59)$. HPV was integrated or predominantly integrated in $75 \%$ of the HNSCC cases, and the E2/E6 ratio did not differ significantly from that of group 3 $\operatorname{hgOED}(p=0.55)$. In a sensitivity analysis comparing the 
Table 1: Characteristics of cervical and head and neck cancer cell lines

\begin{tabular}{|c|c|c|c|c|c|c|c|c|}
\hline \multirow[b]{2}{*}{ Cell lines } & \multirow[b]{2}{*}{$\begin{array}{c}\text { HPV } \\
\text { infection }\end{array}$} & \multirow[b]{2}{*}{$\begin{array}{l}{ }^{\text {aViral }} \\
\text { load }\end{array}$} & \multicolumn{2}{|c|}{ DNA copy number } & \multirow{2}{*}{$\begin{array}{c}\text { Full E2 } \\
\text { DNA } \\
\text { PCR }\end{array}$} & \multicolumn{3}{|c|}{${ }^{\mathrm{c}} \mathrm{mRNA}$ expression } \\
\hline & & & ${ }^{\mathrm{b}} \mathrm{E} 2 / \mathbf{E} 6$ & $\begin{array}{l}\text { Integration } \\
\text { status }\end{array}$ & & $\begin{array}{c}\text { E6/E7 } \\
\text { d(q6/q7 }= \\
\text { ratio })\end{array}$ & p16 ${ }^{\mathrm{INK} 4 \mathrm{a}}$ & EGFR \\
\hline $\mathrm{SiHa}$ & HPV16 & 2 & $0 / 0.1=0.0$ & integrated & no & ${ }^{\mathrm{e} N} \cdot \mathrm{T}$ & N.T & N.T \\
\hline CaSki & HPV16 & 325 & $\begin{array}{c}2.6 / 21.8= \\
0.12\end{array}$ & fmixed & yes & N.T & N.T & N.T \\
\hline UMSCC-1 & uninfected & gN.A & N.A & N.A & N.A & N.A & 0.46 & 0.68 \\
\hline UMSCC-47 & HPV16 & 2 & $0 / 0.08=0.0$ & integrated & yes & $2.0 / 0.08=24.0$ & 2.5 & 0.71 \\
\hline UMSCC-104 & HPV16 & 2 & $\begin{array}{c}0.003 / 0.068= \\
0.045\end{array}$ & mixed & yes & $\begin{array}{c}1.25 / 12.54= \\
0.09\end{array}$ & 1.84 & 0.93 \\
\hline
\end{tabular}

${ }^{a}$ Viral copies per cell.

${ }^{\mathrm{b}}$ Ratio of $E 2$ (picograms, pg) to $E 6(\mathrm{pg})$ as determined from the standard curves of the respective genes by a previously. described quantitative real-time PCR assay [44]

'mRNA expression: By the $\Delta \Delta \mathrm{Ct}$ method (The values are expressed in percentage of $2^{-\Delta \mathrm{Ct}}$ ).

${ }^{\mathrm{d}} \mathrm{q} 6 / \mathrm{q} 7$ = quantification (pg) of $E 6 \mathrm{mRNA} /$ quantification (pg) of $E 7 \mathrm{mRNA}$

eN.T: not tested.

${ }^{\mathrm{f}}$ Mixed: This sample contains both episomal and integrated forms of HPV.

gN.A: not applicable.

$E 2 / E 6$ ratios of only the OPC cases $(N=10)$ to those of the group 3 hgOED cases, there was still no significant difference $(p=0.97)$.

\section{HPV LCR methylation status}

All the $\mathrm{CpG}$ target sites of the cellular methyltransferase were identified within the HPV16 LCR, which contains the promoter and various transcription factor binding sites. CpGs were found in 15 sites each in $\mathrm{SiHa}, \mathrm{CaSki}$ and UMSCC-104 cells and at 13 locations in UMSCC-47 cells, due to two reported point mutations in the latter (nucleotide $7434 \mathrm{CG}>\mathrm{CA}$ and nucleotide $31 \mathrm{CG}>\mathrm{TG}$ ) [42]. The binding sequences that contain CpGs are indicated in Table 3, along with the nucleotide location of each $\mathrm{CpG}$ site. A variety of promoter methylation patterns were observed in the four cancer cell lines. We observed evidence of hypermethylation in CaSki and UMSCC-47 cells $(93.33 \%$ and $76.92 \%$ of the available CpGs, respectively). The two cells lines shared one unmethylated site (nucleotide 7862 within E2BS2), and UMSCC-47 had additional unmethylated CpGs at nucleotides 7676 and 7682. In contrast, all 15 CpG sites within the LCR were unmethylated in $\mathrm{SiHa}$ and UMSCC-104 cells.

Methylation analysis revealed that all the $\mathrm{CpG}$ sites were unmethylated in all the samples in all three hgOED groups. Similarly, except for three samples exhibiting methylation $(93.33 \%, 60 \%$ and $26.67 \%$ methylation respectively, Table 3), the HNSCC specimens were predominantly unmethylated within the LCR. Thus, there was an overall pattern of hypomethylation of the HPV epigenome in the patient samples.

\section{DISCUSSION}

While viral integration and methylation are key processes in HPV-associated cervical cancer [7, 13, 14, 43], their involvement in head and neck carcinogenesis is not well understood. We used human hgOED and HNSCC samples and HNSCC cell lines to explore patterns of HPV DNA integration and methylation that could contribute to tumor development.

It is well documented [44] that $\mathrm{SiHa}$ cells have two copies of HPV16 DNA integrated into the host genome, as indicated by disrupted $E 2$ sequences. Therefore, we compared the integration patterns of other cell lines and the hgOED samples with that of SiHa cells (Table 1 and Figure 1). Our data indicated that CaSki cells contained a mixture of integrated and episomal HPV16 DNA (Table 1). The HPV-positive HNSCC cell lines, UMSCC-47 and UMSCC-104, exhibited similar copy numbers of HPV16 DNA, and possessed integrated or both episomal and integrated (i.e., mixed) forms of HPV, respectively (Table 1 ). We found a very weak PCR band of full-sized E2 DNA in UMSCC-104 cells (Table 1 and Figure 1B), indicating the presence of episomal viral DNA. These results are consistent with data from Akagi et al. [21], but conflict with the results of Olthof et al., who reported the presence of solely episomal HPV in UMSCC-104 cells [20]. This discrepancy may be attributed to Olthof's use of a set of primers that did not span the full length of $E 2$, and to the unique integration breakpoint of this cell line (Figure 1C), as reported by Akagi et al. [21]. Additionally, we found evidence of E2 mRNA expression in both HNSCC cell lines (Figure 2), in contrast to a previous report that the $E 2$ gene was not 
intact and E2 mRNA was not detectable in UMSCC-104 cells [45].

Since both of the HPV-positive HNSCC cell lines in this study contained integrated HPV DNA, it was not possible to make definitive conclusions about the relationship between viral oncogene expression and integration status. However, we did find significant differences in E2, E6 and E7 expression between UMSCC-47 (integrated DNA) and UMSCC-104 (mixed DNA with predominantly integrated HPV) cells that were worthy of exploration (Figure 3). While E2 mRNA expression was slightly higher in UMSCC-104 cells than in UMSCC-47 cells, the difference was not statistically significant. This lack of difference was due to a limitation of the assay, in that the primers bind upstream of the integration breakpoint in $E 2$, enabling the detection of functional and truncated E2 mRNA in UMSCC-47 cells.
E6 oncogene mRNA expression was significantly greater $(p<0.0351)$ in UMSCC-47 than in UMSCC-104 cells (Figure 2). We interpret these results to indicate that the E2 protein transcribed from integrated HPV in UMSCC-47 cells was truncated and nonfunctional, and thus was unable to perform its function as a transcriptional repressor of E6. In contrast, the E2 protein from the episomal HPV in UMSCC-104 was functional and expressed at a slightly higher level, and thus was able to repress E6 expression. However, in the case of the E7 oncogene, a large difference $(p<0.001)$ in mRNA expression was found. This expression profile was unexpectedly the opposite of that of E6, with higher expression in the UMSCC-104 cell line. This finding suggests that a mechanism unrelated to transcriptional repression by $\mathrm{E} 2$, such as epigenetic regulation (to be discussed shortly) may be related to HPV E7 oncogene expression.

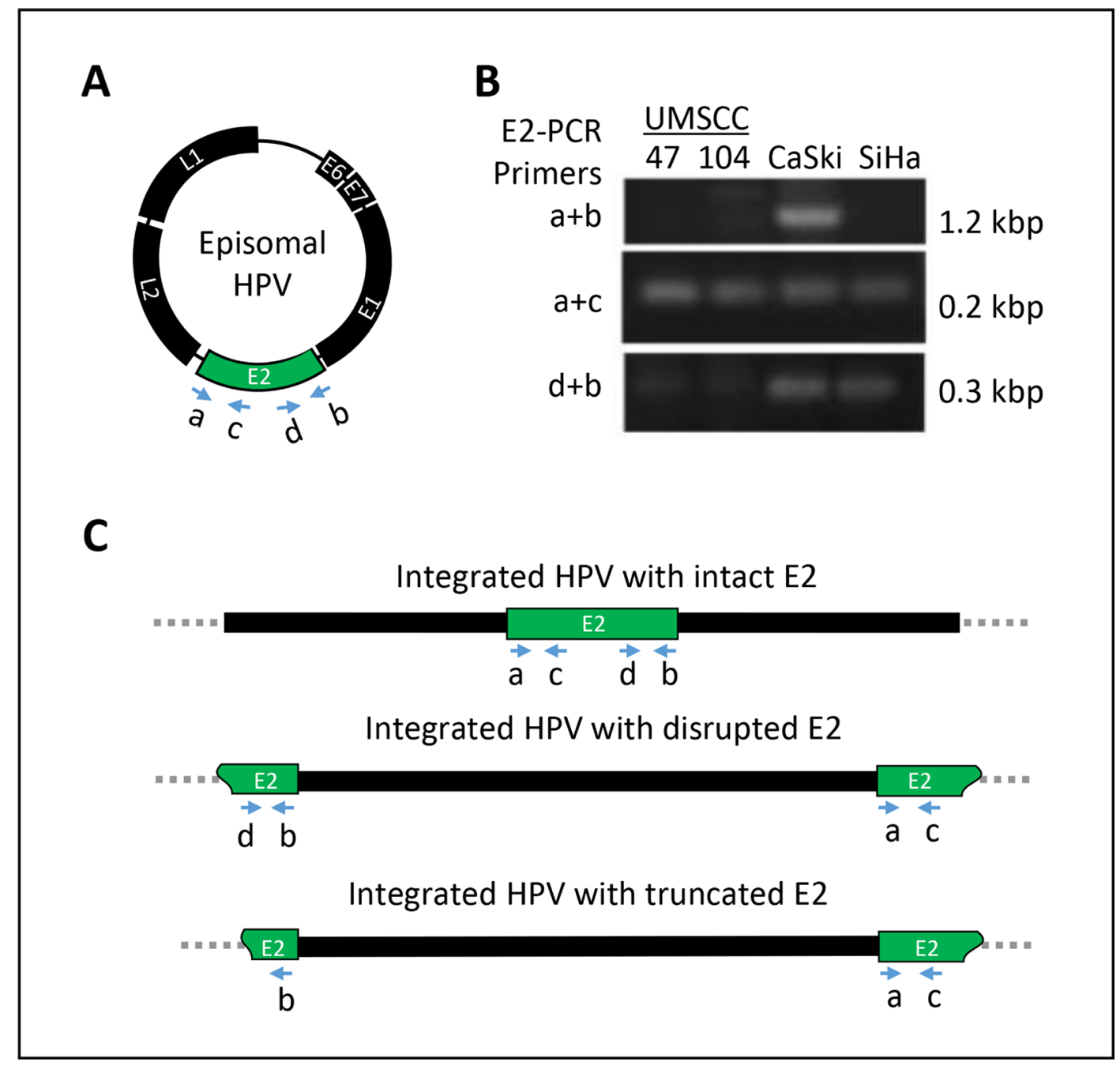

Figure 1: Determination of E2 gene integrity (A) by means of HPV16 E2 primers (16E2 a, b, c and d, Supplementary Table 1) which detect the intact or disrupted E2 gene. (B) Agarose gel image displaying the full-length E2 in CaSki cells and disrupted E2 sequences in SiHa, UMSCC-47 and UMSCC-104 cells. (C) Schematic representation of three different ways that HPV DNA can integrate into the host chromosome. 
The overexpression of $\mathrm{p} 16^{\mathrm{INK} 4 \mathrm{a}}$ has been observed in HPV-positive cancers [40, 41]. Consistently, we found that $p 16^{I N K 4 a}$ expression was significantly higher in the HPV-positive HNSCC cell lines than in the HPV-negative UMSCC-1 cell line. The E7 protein is known to upregulate p16 $6^{\mathrm{INK} 4 \mathrm{a}}$ by inactivating pRB [46], but we could not find any relationship between $E 7$ and $p 16^{I N K 4 a}$ expression in the cell lines we tested. Another marker used clinically is EGFR, which is frequently overexpressed in HNSCC independent of HPV etiology [47, 48] and portends a poor prognosis [49]. We found significantly higher EGFR expression in the UMSCC-104 cell line, which originated from an HPV-positive tumor that did not respond to treatment [50], than in UMSCC-1 cells.

In addition to viral integration, DNA methylation can promote HPV-associated carcinogenesis by impairing E2 function, thereby increasing E6 and E7 oncogene expression [51, 52]. Methylation of the HPV LCR and L1 sequences has been associated with an increased grade of cervical neoplasia [8, 9], and LCR methylation is a known epigenetic mechanism [43, 53-56]. We found important differences in methylation in the cancer cell lines, with UMSCC-47 cells exhibiting hypermethylation (similar to CaSki cells), and UMSCC-104 cells displaying hypomethylation (similar to $\mathrm{SiHa}$ cells). The LCR methylation profiles obtained in this study could be used to differentiate the HNSCC cell lines by methylation status (hyper- or hypomethylated) (Table 3). However, an association between LCR methylation and cancer type was not observed. Instead, the LCR methylation pattern and integration status differed between the HNSCC cell lines: UMSCC-47 cells, with only integrated DNA (similar to $\mathrm{SiHa}$ cells), were hypermethylated (resembling CaSki cells), while UMSCC-104 cells, which contained mixed forms of HPV DNA, were hypomethylated, in agreement with the findings of others [45]. Thus, there was no observable relationship between the methylation pattern and the presence of integration.

However, in the HNSCC cell lines with predominantly integrated HPV, the methylation patterns may have been associated with the $E 6$ and $E 7$ expression profiles. E7 expression was substantially greater in

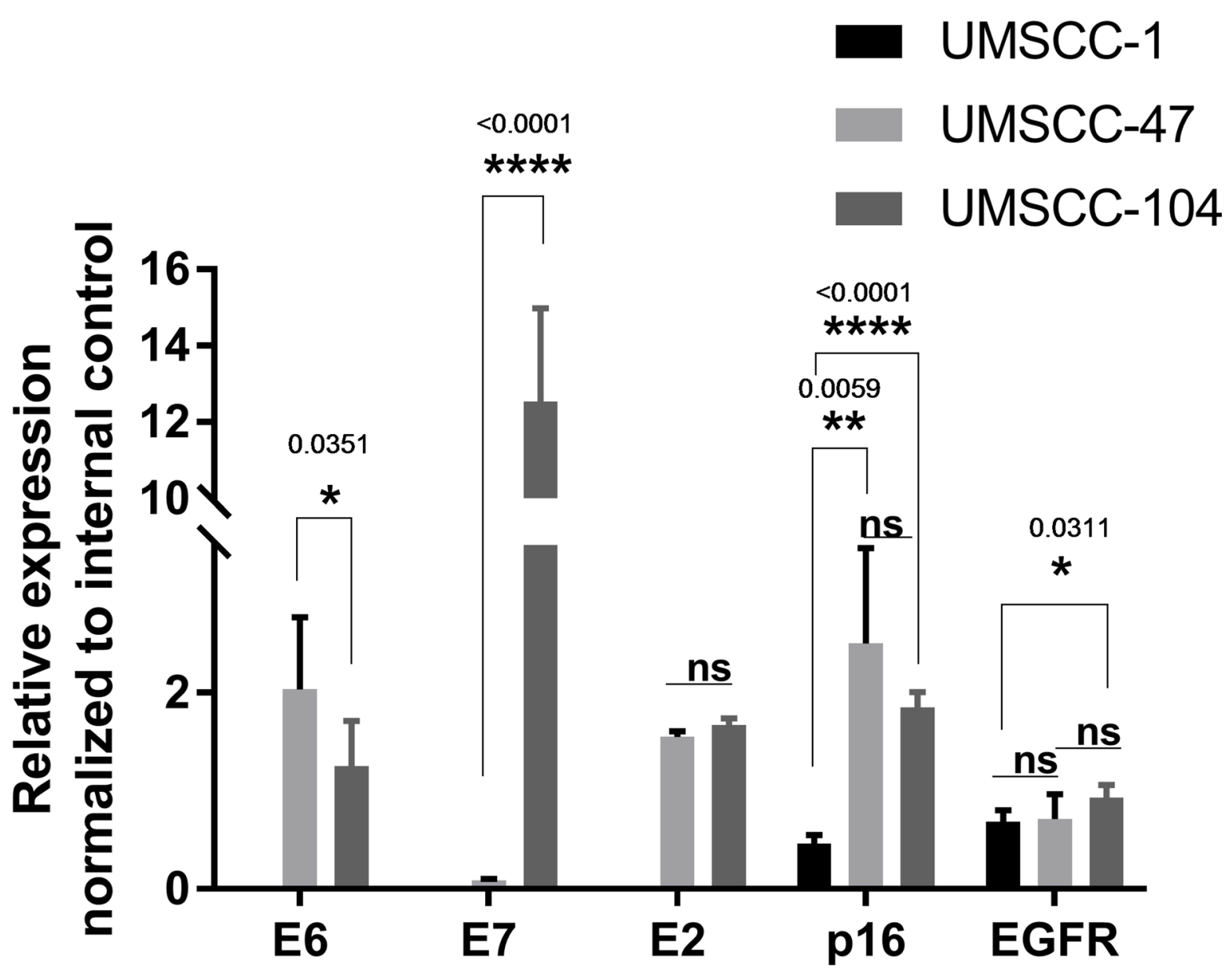

Figure 2: Relative expression of $E 6, E 7, E 2, p 16$ and $E G F R$ in UMSCC-1, UMSCC-47 and UMSCC-104 head and neck cancer cell lines. $P$-values $<0.05$ were considered significant. Statistical significance levels at ${ }^{*} p<0.05,{ }^{* *} p<0.01$ and ${ }^{* * * *} p<0.0001$ are indicated. ns represents non-significant. Statistical analyses were performed with Student's $t$-test (unpaired two-tailed) in GraphPad Prism. E2 primers were designed upstream of the E2 breakpoint. 
Table 2: Viral loads and E2/E6 ratios in HPV16-positive hgOED and HNSCC

\begin{tabular}{|c|c|c|c|c|}
\hline \multicolumn{2}{|c|}{ Epithelial disease category } & Histologic group ${ }^{a}$ & $\begin{array}{c}\text { Viral load }^{\mathrm{b}} \text {, median [Q1, Q3] } \\
p \text {-value vs. G3 }\end{array}$ & $\begin{array}{c}\text { E2/E6 ratioc } \text {, median }[\mathrm{Q} 1, \mathrm{Q} 3] \\
\text { p-value vs. G3 }\end{array}$ \\
\hline \multirow{3}{*}{\multicolumn{2}{|c|}{$\begin{array}{l}\text { Premalignant Lesions } \\
\text { (hgOED) }\end{array}$}} & G1 & $\begin{array}{c}0.009[0.002,0.026] \\
p=0.002\end{array}$ & $\begin{array}{c}0.76[0.55,0.88] \\
p=0.002\end{array}$ \\
\hline & & G2 & $\begin{array}{c}0.04[0.02,0.97] \\
\quad p=0.03\end{array}$ & $\begin{array}{c}0.41[0.39,0.46] \\
p=0.03\end{array}$ \\
\hline & & G3 & $\begin{array}{c}7.75[4.54,15.81] \\
\text { N.A. }\end{array}$ & $\begin{array}{c}0.04[0.02,0.26] \\
\text { N.A. }\end{array}$ \\
\hline \multirow{2}{*}{$\begin{array}{l}\text { Malignant } \\
\text { lesions } \\
\text { (HNSCC) }\end{array}$} & All HNSCC & N.A. & $\begin{array}{c}3.61[1.64,18.54] \\
\quad p=0.59\end{array}$ & $\begin{array}{c}0.05[0.03,0.42] \\
p=0.55\end{array}$ \\
\hline & $\begin{array}{l}\text { Oropharyngeal } \\
\text { Only }\end{array}$ & N.A. & $\begin{array}{c}7.93[1.87,20.54]^{\mathrm{d}} \\
p=0.83^{\mathrm{e}}\end{array}$ & $\begin{array}{c}0.04[0.01,0.45]^{\mathrm{d}} \\
p=0.97^{\mathrm{e}}\end{array}$ \\
\hline
\end{tabular}

Abbreviations: G1: group 1; G2: group 2; G3: group 3.

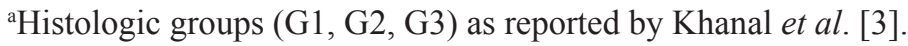

${ }^{b}$ Viral load normalized to that of SiHa cells.

${ }^{c} E 2 / E 6$ ratio used to determine DNA integration status.

dSummary statistics for the malignant HNSCC group after the removal of non-oropharyngeal samples $(N=10)$.

"Statistical significance of oropharyngeal samples only: The $p$-value for "All HNSCC" represents the statistical significance of the Wilcoxon rank-sum test with all malignant samples $(N=15)$ included, while the $p$-value for "Oropharyngeal Only" represents the statistical significance after the removal of non-oropharyngeal samples $(N=10)$ (sensitivity analysis).

UMSCC-104 cells, which contained a hypomethylated LCR $(0 \%)$, than in UMSCC-47 cells, which contained a hypermethylated LCR (76.9\%). However, E6 expression was only slightly higher in UMSCC-47 cells than in UMSCC-104 cells. These results suggest that LCR methylation may be more strongly associated with $E 7$ expression than with E6 expression when HPV DNA is integrated.

To determine the association between $E 7$ expression and LCR methylation, we focused on the epigenetic regulation of oncogene transcription during HPV pathogenesis [10, 11]. The complete suppression of $E 7$ via hypermethylation of the LCR in UMSCC-47 cells clearly demonstrated this effect. Because most of the $\mathrm{CpG}$ sites in E2BS2 sequences were methylated in CaSki cells, we hypothesized that methylation may inhibit the binding of $\mathrm{E} 2$ to $\mathrm{E} 2 \mathrm{BS} 2$, thus increasing $E 6$ and $E 7$ expression despite the presence of E2. However, when E2 is absent, as it is in SiHa and UMSCC-47 cells, LCR transcriptional regulatory sequences are the main target of methylation, leading to the suppression of E7. The high $E 7$ expression in UMSCC-104 cells with an unmethylated LCR and little to no E2 decisively indicated that methylation of the viral LCR strongly downregulates E7 expression.

The few studies that have examined viral DNA methylation in HNSCC have reported divergent results [37, 38, 45, 57]. Wilson et al. [37] and Park et al. [38] reported hypomethylation of the LCR region in 3 and 22 OPC cases, respectively. Balderas-Loaeza et al. [57] reported hypermethylation in the LCR and an additional site in the $L 1$ gene in 10/12 oral carcinomas $(83.3 \%)$. The promoter region was completely methylated in three of these cases, with an overall methylation rate of $28.2 \%$. Reuschenbach et al. [45] assessed the methylation and viral integration status of 57 cases of OPC, and concluded that methylation of the LCR varied based on integration status. Tumors with complete methylation (greater than $80 \%$ ) or low methylation (0-20\%) were associated with integration, while those with an intermediate methylation pattern $(20-80 \%)$ had predominantly episomal viral genomes.

Our analysis of clinical hgOED and HNSCC samples (Table 3) supported the previously documented conclusion that most malignant specimens are unmethylated, and that there are no significant methylation differences between premalignant and malignant lesions. Each of the three malignant HNSCC samples that were methylated had near-complete integration, with E2/E6 ratios of 0.003 (HNSCC 7), 0.02 (HNSCC 2) and 0.03 (HNSCC 10). Methylated CpGs were located at various sites within the LCR, but no specific pattern was identified. Accordingly, while an increase in methylation may occur in some tumors, it does not appear to be a significant factor in most cases of HNSCC. While Balderas-Loaeza et al. reported hypermethylation in OSCC [57], we did not observe any LCR methylation in our cases of hgOED; thus, the involvement of methylation in oral premalignancy and OSCC remains unresolved.

The viral loads and integration rates of our hgOED samples suggested a potentially important relationship between histologic appearance and viral integration. As cytologic alterations increased across the three hgOED 
groups, the viral load and integration of HPV also increased (Table 2, Figure 3), with integration of HPV in all group 3 cases. In contrast, episomal HPV was the predominant form in group 1 hgOED cases. Thus, when increased cytologic changes $(\geq 5.3 / \mathrm{hpf})$ are observed during routine microscopic examination in a case of hgOED, there is a significant likelihood that HPV16 is present [3] and integrated into the host genome. It should be noted that only $25 \%$ of our malignant cases of OPC had episomal forms, while much higher rates have been

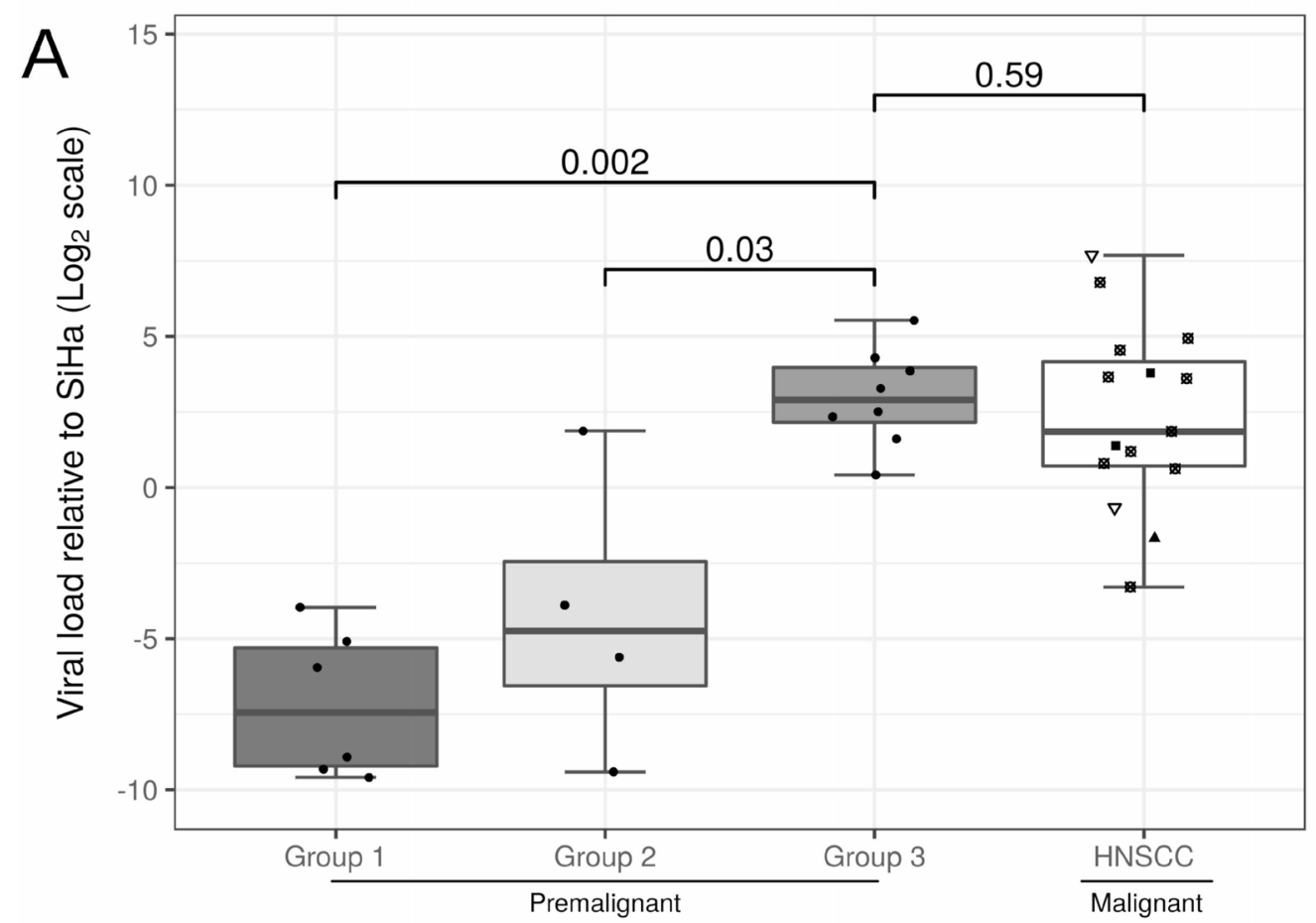

\section{Anatomic site}

Oropharyngeal

- Hypopharyngeal

$\nabla$ Laryngeal

- Oral

- Premalignant

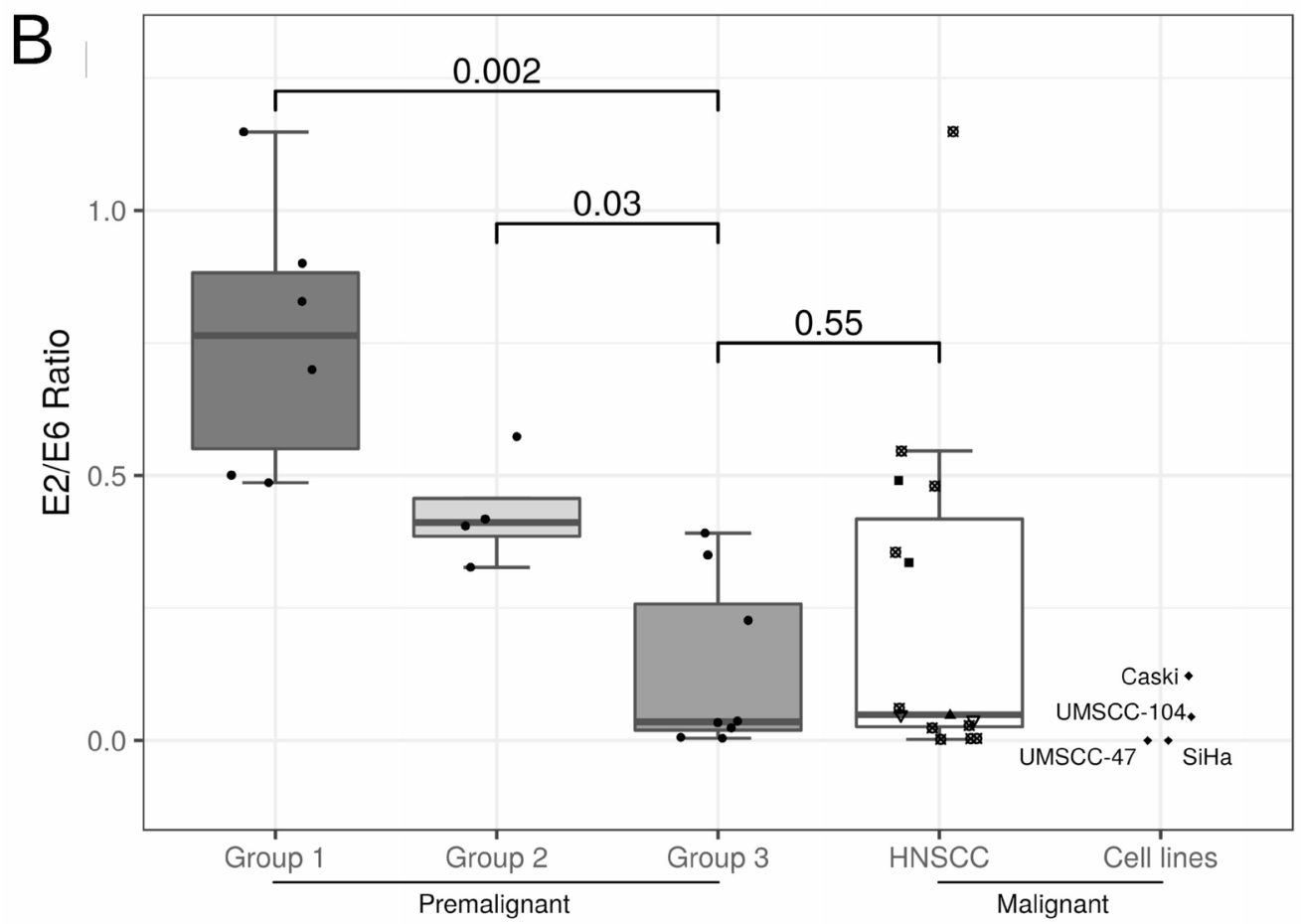

\section{Anatomic site}

- Oropharyngeal

- Hypopharyngeal

$\nabla$ Laryngeal

- Oral

- Premalignant

- Cell lines

Figure 3: (A) Box plot of the viral load in each sample normalized to the level in SiHa cells and (B) box plot of the E2/E6 ratio, indicative of the degree of viral DNA integration. In both analyses, premalignant cases (group 1: $N=6$, group 2: $N=4$ and group 3: $N=8$ ) were compared with malignant samples (HNSCC), while the four cancer cell lines were added to the second plot. Pairwise Wilcoxon rank-sum tests were conducted, and multiplicity-adjusted $p$-values (Holm's method) are presented in the figure. 
Table 3: Methylation of CpG sites in cervical and OSCC cell lines and hgOED and HNSCC specimens

\begin{tabular}{|c|c|c|c|c|c|c|c|c|c|c|c|c|c|c|c|c|}
\hline \multirow{3}{*}{$\begin{array}{l}\text { HPV genome } \\
\text { CpG site }^{\#}\end{array}$} & \multicolumn{4}{|c|}{ 5'-LCR } & \multicolumn{5}{|c|}{ Enhancer } & \multicolumn{7}{|c|}{ Promoter } \\
\hline & \multicolumn{2}{|c|}{ YY1 } & \multicolumn{2}{|c|}{ E2BS1 } & \multirow{2}{*}{$\frac{\text { NF1 }}{5}$} & \multirow{2}{*}{$\frac{\text { NF1 }}{6}$} & \multirow{2}{*}{$\frac{\text { YY1 }}{7}$} & \multirow{2}{*}{$\frac{\text { AP1 }}{8}$} & \multirow{2}{*}{$\begin{array}{c}\text { Tef } \\
9\end{array}$} & \multirow{2}{*}{$\begin{array}{c}\text { E2BS2 } \\
10\end{array}$} & \multirow{2}{*}{$\frac{\text { SP1 }}{11}$} & \multicolumn{2}{|c|}{ E2BS3 } & \multicolumn{2}{|c|}{ E2BS4 } & \multirow{2}{*}{$\frac{\text { TATA }}{\mathrm{p} 97}$} \\
\hline & 1 & 2 & 3 & 4 & & & & & & & & 12 & 13 & 14 & 15 & \\
\hline Sample $^{\mathrm{a}}$ NT & 7428 & 7434 & 7455 & 7461 & 7535 & 7553 & 7676 & 7682 & 7694 & 7862 & 31 & 37 & 43 & 52 & 58 & $\%$ Methylation \\
\hline $\mathrm{SiHa}$ & $\mathrm{U}$ & $\mathrm{U}$ & $\mathrm{U}$ & $\mathrm{U}$ & $\mathrm{U}$ & $\mathrm{U}$ & $\mathrm{U}$ & $\mathrm{U}$ & $\mathrm{U}$ & $\mathrm{U}$ & $\mathrm{U}$ & $\mathrm{U}$ & $\mathrm{U}$ & $\mathrm{U}$ & $\mathrm{U}$ & 0 \\
\hline CaSki & M & M & M & M & M & M & M & M & M & $\mathrm{U}$ & M & $\mathrm{M}$ & M & M & $\mathrm{M}$ & 93.33 \\
\hline UMSCC-47b & M & Mut & M & M & M & M & $\mathrm{U}$ & $\mathrm{U}$ & M & $\mathrm{U}$ & Mut & M & $\mathrm{M}$ & M & $\mathrm{M}$ & 76.92 \\
\hline UMSCC-104 & $\mathrm{U}$ & $\mathrm{U}$ & $\mathrm{U}$ & $\mathrm{U}$ & $\mathrm{U}$ & $\mathrm{U}$ & $\mathrm{U}$ & $\mathrm{U}$ & $\mathrm{U}$ & $\mathrm{U}$ & $\mathrm{U}$ & $\mathrm{U}$ & $\mathrm{U}$ & $\mathrm{U}$ & $\mathrm{U}$ & 0 \\
\hline HNSCC 2 & M & M & M & M & $\mathrm{U}$ & $\mathrm{U}$ & $\mathrm{U}$ & $\mathrm{U}$ & $\mathrm{U}$ & $\mathrm{U}$ & M & $\mathrm{M}$ & M & M & M & 60.0 \\
\hline HNSCC 7 & M & M & M & M & M & M & M & M & M & $\mathrm{U}$ & M & $\mathrm{M}$ & $\mathrm{M}$ & M & $\mathrm{M}$ & 93.33 \\
\hline HNSCC 12 & $\mathrm{U}$ & $\mathrm{U}$ & $\mathrm{U}$ & $\mathrm{U}$ & $\mathrm{U}$ & M & $\mathrm{U}$ & $\mathrm{U}$ & $\mathrm{U}$ & $\mathrm{U}$ & M & $\mathrm{U}$ & $\mathrm{U}$ & M & $\mathrm{M}$ & 26.67 \\
\hline
\end{tabular}

Abbreviations: YY1, NF1, AP1, Tef, SP1: transcription factor binding sites; TATA: Tata box sequence; " number; NT: nucleotide position; p97: Early promoter of HPV at 97 NT; U: unmethylated; M: Methylated; Mut: mutated.

aThe remaining $12 \mathrm{HNSCC}$ and all 18 premalignant hgOED specimens were unmethylated at all $15 \mathrm{CpG}$ sites

bUMSCC-47 only has $13 \mathrm{CpG}$ sites due to two known point mutations.

reported in other studies [22,32]. Carcinogenesis may still occur in cases with episomal DNA; indeed, this has been reported for the cervix, where episomal HPV still regulates oncogene activity [58], but may activate alternative oncogenic pathways [56].

Our finding of increasing integration with increasing cytologic alterations paralleled the pattern found in cervical cancer and was strikingly similar to the integration rates in our HNSCC cases and cell lines [7, 13-18]. Despite the inconclusive results of published work, we suspected that integration would be a significant factor in HNSCC, partially based on its high frequency of detection [24, 28, 59]. What is the clinical significance of the correlation we detected between viral integration and cytologic alterations? Could this histologic change herald malignant transformation? An expanded clinical study is needed to confirm the ability of our HPV-OED grading system to predict malignant transformation.

While the function of HPV as the driving force behind the malignant progression from hgOED to OSCC may be different than what has been established in $\mathrm{OPC}$, it is reasonable to assume that many of the same mechanisms are involved. Accordingly, further analysis of HPV-OED cases may reveal HPV-induced transformative mechanisms that apply to all HPV-associated cases of HNSCC. Likewise, we believe that our examination of the viral integration and methylation of HNSCC cell lines can be effectively applied to HPV-associated cancers of the oral cavity.

\section{MATERIALS AND METHODS}

\section{Sample collection}

This study was approved by the Institutional Review Board at the University of Louisville. Formalinfixed paraffin-embedded (FFPE) specimens of hgOED $(N=38)$ were obtained from the University of Louisville
Oral Pathology Laboratory (Louisville, KY, USA) from April 2003 to February 2015 as previously described [3]. Fresh, frozen or FFPE tissues from cases of HNSCC $(N=50)$ were collected from 2006 to 2015 from the Cancer Database and Specimen Repository at the James Graham Brown Cancer Center (Louisville, KY, USA). University of Michigan Squamous Cell Carcinoma (UMSCC) oral cavity cancer cell lines (HPV-negative [UMSCC-1]; HPV-positive [UMSCC-47 and UMSCC-104]) [20, 50, 60] were purchased from EMD Millipore Corporation (Temecula, CA, USA) and cultured by standard protocols. Cervical cancer cell lines (CaSki and $\mathrm{SiHa}$ ) were cultured as suggested by the American Type Culture Collection (Manassas, VA, USA).

\section{DNA extraction and HPV detection}

DNA was extracted from fresh, frozen or FFPE specimens with a DNAeasy Blood \& Tissue Kit (Qiagen, Germantown, MD, USA) per the manufacturer's instructions with RNase treatment $(20 \mu \mathrm{L}$ of $20 \mathrm{mg} / \mathrm{mL})$. FFPE samples were deparaffinized with xylene and washed before DNA extraction. HPV detection and genotyping were performed with $16 E 7$ primers (Supplementary Table 1), and $\beta$-globin was used as an internal control, as previously described [61]. HPV16positive cases (18/38 for hgOED and 16/50 for HNSCC) were then used in HPV DNA integration and methylation studies. The method whereby cases were screened and selected for integration and methylation analyses is presented in Figure 4. Of the HNSCC cases, 10 were oropharyngeal and 5 were from other head and neck sites ( 2 oral cavity, 2 laryngeal and 1 hypopharyngeal).

\section{HPV integration and viral load assessment by quantitative PCR}

We employed a previously described quantitative real-time PCR assay to evaluate the viral load and 
integration in cell lines and HNSCC specimens [44]. E6 primers and probes were used to analyze the viral load in the cell, and $\beta$-globin was used as an internal control (Supplementary Table 1). We analyzed the copy numbers of target DNA per $20 \mathrm{ng}$ of total genomic DNA using a quantitative PCR-based absolute quantification method [44]. In a total volume of $20 \mu \mathrm{L}$, the final primer and probe concentrations and DNA template amounts were $0.3 \mu \mathrm{M}, 0.1 \mu \mathrm{M}$ and $20 \mathrm{ng}$, respectively. TaqMan ${ }^{\mathrm{TM}}$ Universal Master Mix II with Uracil-N-glycosylase was used according to the manufacturer's instructions (Thermo Fisher Scientific, Waltham, MA, USA). An HPV16 plasmid cloned in a pBR322 vector was used to plot a standard curve (300 pg to $0.3 \mathrm{pg}$ ). Water controls were included in each run. All experiments were performed in duplicate at least three times. We estimated the relative viral load by calculating the copy number ratio of $E 6$ in the specimen to E6 in the SiHa cell line, which is known to contain two copies of HPV16 DNA per cell [44].

HPV integration status was evaluated based on the E2/E6 ratio. The primers and probes were designed for specific amplification of the E2 hinge regions that are known to be disrupted most frequently during the process of viral integration (Supplementary Table 1) [44]. An $E 2 / E 6$ ratio $\geq 1$ indicates episomal HPV DNA with no integrated forms, while a ratio of 0 indicates integrated
HPV DNA with no episomal forms, and a ratio $>0$ and $<1$ indicates a "mixed" result of both episomal and integrated forms. Cervical cancer cell lines (CaSki and $\mathrm{SiHa}$ ) were used as positive controls for the study of HPV DNA integration. We analyzed the copy numbers of HPV DNA per $20 \mathrm{ng}$ of total genomic DNA in human tissue specimens by the same method. SiHa cells were also used as a reference to estimate the relative viral copy numbers of the tissue specimens.

\section{Determination of $\boldsymbol{E} 2$ gene integrity}

The integrity of the E2 gene was determined by amplification of the full-length $E 2$ open reading frame (nucleotides 2755 to 3852 of NC_001526.2; primers 16E2a and E2b listed in Supplementary Table 1). Disruption of this region was defined as the absence of the full-length E2 amplicon in agarose gel electrophoresis and a positive signal of parallel $\beta$-actin amplification. As CaSki cells carry an intact E2 gene, the positive amplification signal of this $\sim 1-\mathrm{kb}$ fulllength $E 2$ amplicon was used as a control. Amplification of the first half of E2 (primers 16E2a and 16E2c) and the last half of the E2 region (primers $16 \mathrm{E} 2 \mathrm{~d}$ and $16 \mathrm{E} 2 \mathrm{~b})$ was performed for further confirmation of $E 2$ integrity.

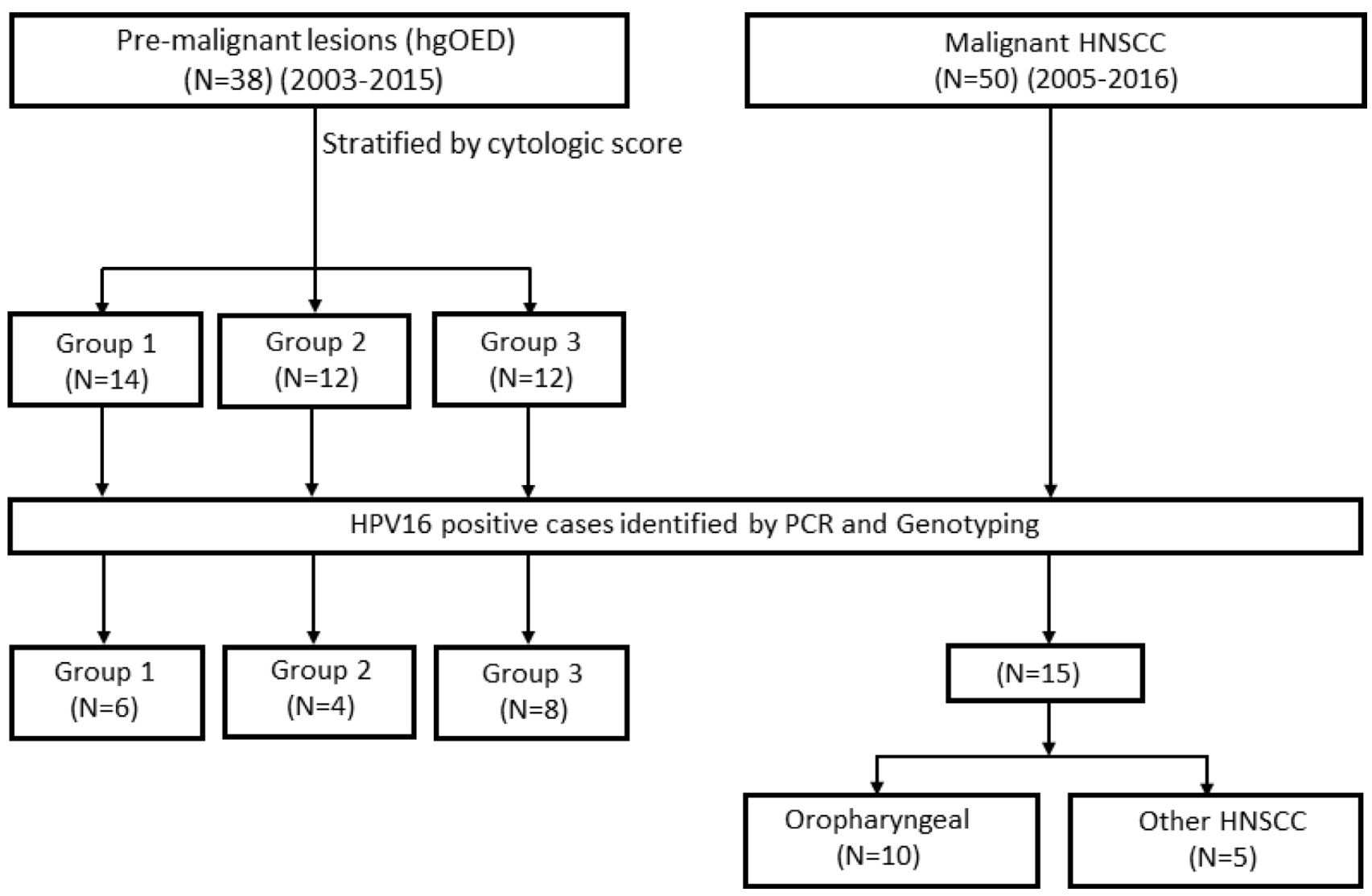

Figure 4: A flow diagram of premalignant and malignant case selection. 


\section{DNA methylation analysis: bisulfite sequencing}

The methylation frequency of HPV DNA was profiled in each cancer cell line and in the cases of hgOED and HNSCC. Methylation on LCR sequences of HPV was assessed because this regulatory region is a known target of DNA methylation that induces transcriptional changes leading to cervical cancer $[8,9]$. Purified genomic DNA was bisulfite-converted by means of an EpiTect ${ }^{\mathbb{B}}$ Plus Bisulfite Kit (Qiagen, USA) according to the manufacturer's protocol. During this treatment, unmethylated cytosine residues are converted to uracil, whereas 5-methylcytosine is unaffected. Target DNA is then amplified by PCR, such that uracil residues are converted to thymine. The DNA methylation status of HPV DNA could thus be evaluated by the direct sequencing of the PCR products.

Because HPV16 has different variants (based on single-nucleotide polymorphisms present in the LCR and/ or E6), an Asian-American variant of HPV16 (GenBank accession number: AF402678.1) was used as a reference HPV16 sequence for primer design and further analysis. The bisulfite-treated DNA was amplified by PCR with different sets of primers designed for the $15 \mathrm{CpG}$ sites in the LCR region of HPV (Supplementary Table 1). Primers were designed within the consensus sequences among different variants of HPV16 (GenBank accession numbers: AF402678.1, AF125673.1, AY686584.1, NC_001526.2 and KF954093.1). Secondary primer sets were adopted in the event that PCR amplification with the primary primers was negative. As an internal control for the presence of bisulfite-modified DNA, we used primers that are specific to a modified region of the $\beta$-actin (ACTB) gene that lacks $\mathrm{CpG}$ sites. The PCR reaction mixtures consisted of $10 \mathrm{X}$ HiFi PCR buffer, $50 \mathrm{mM} \mathrm{MgSO}_{4}, 10 \mathrm{mM}$ deoxynucleotide triphosphates, $20 \mu \mathrm{M}$ of each primer and $1 \mathrm{U}$ of HiFi Taq polymerase (Thermo Fisher Scientific, USA) in a total volume of $20 \mu \mathrm{L}$. The PCR conditions were $2 \mathrm{~min}$ at $95^{\circ}$ $\mathrm{C} ; 45$ cycles of $45 \mathrm{sec}$ at $95^{\circ} \mathrm{C}, 45 \mathrm{sec}$ at $52^{\circ} \mathrm{C}$ and 45 sec at $68^{\circ} \mathrm{C}$; and $10 \mathrm{~min}$ at $68^{\circ} \mathrm{C}$. The PCR products were separated on a $3 \%$ agarose gel, extracted with a QIAquick Gel Extraction Kit (Qiagen, USA) and sent to the DNA Core Facility at the University of Louisville for sequencing. Amplified products were directly sequenced with the same primers. Sequencing data were aligned with the NCBI BLAST database and the SeqMan Pro program (Lasergene 12, DNAstar Inc., Madison, WI, USA).

\section{RNA extraction and qRT-PCR analysis}

Total RNA was isolated from cultured UMSCC-1, -47 and -104 cells with a PureLink ${ }^{\circledR}$ RNA Mini Kit (Thermo Fisher Scientific, USA) and treated with DNase I, according to the manufacturer's instructions. Singlestranded complementary DNA (cDNA) was synthesized from $1 \mu \mathrm{g}$ of total RNA with a SuperScript ${ }^{\circledR}$ VILO cDNA
Synthesis Kit (Thermo Fisher Scientific, USA) according to the manufacturer's instructions. qRT-PCR was performed in separate $20-\mu \mathrm{L}$ reaction volumes to evaluate the expression of HPV16 genes $E 6, E 7$ and $E 2$ and cellular genes p16 (CDKN2a/INK4a), EGFR and $\beta$-actin. For the analysis of $E 2$ gene expression, primers were designed near the $5^{\prime}$ end and upstream of the frequent $E 2$ breakpoint to monitor the relative expression of truncated $E 2$ mRNA. qRT-PCR was performed in triplicate on an Applied Biosystems VIIa ${ }^{\mathrm{TM}} 7$ Real-Time PCR detection system (Thermo Fisher Scientific, USA) with 100 ng of cDNA as a template, along with the gene-specific forward and reverse primers $(0.3 \mu \mathrm{M}$ each) (Supplementary Table 1$)$ and the Power SYBR ${ }^{\circledR}$ Green Supermix (Thermo Fisher Scientific, USA). The amplification program for all primer sets was $95^{\circ} \mathrm{C}$ for 3 minutes, followed by 40 cycles of $95^{\circ} \mathrm{C}$ for 15 seconds and $60^{\circ} \mathrm{C}$ for 60 seconds. Realtime PCR amplification data were analyzed and cycle threshold $(\mathrm{Ct})$ numbers were automatically determined by VIIa $^{\mathrm{TM}} 7$ software v1.2.4 (Thermo Fisher Scientific, USA). The relative expression of each mRNA was calculated by the $\Delta \mathrm{Ct}$ method [62]. Endogenous $\beta$-actin mRNA levels were used for the normalization of mRNA expression. Due to the small amounts of mRNA recovered from clinical biopsies, qRT-PCR was only performed on cell lines and not on clinical biopsy samples.

\section{Statistical analysis}

As the distribution of the viral load and the E2/ E6 ratio significantly departed from approximate normality, non-parametric tests were used to compare the distribution of these measures across the study groups. For both measures, the sample medians are reported, along with the first and third quartiles (representing the 25th and 75th percentiles, respectively). For pairwise comparisons, Wilcoxon rank-sum tests were conducted, and multiplicity-adjusted $p$-values (determined by Holm's method [63] to preserve the familywise error rate at less than or equal to 0.05 ) are reported. Given that the evaluated oropharyngeal cases $(N=10)$ could have exhibited different characteristics than HNSCC cases at other head and neck locations, a sensitivity analysis was conducted to assess only this group without the remaining non-oropharyngeal cases $(N=5)$. Statistical analyses were performed with the following functions from the $\mathrm{R}$ environment for statistical computing (version 3.4.2): stats, ggplot 2 and ggsignif. The relative gene levels in UMSCC cell lines were analyzed with GraphPad Prism 7 (GraphPad Software, La Jolla, CA, USA).

\section{Abbreviations}

hPV16: human papillomavirus type 16; HNSCC: head and neck squamous cell carcinoma; hgOED: high-grade oral epithelial dysplasia; HPV-OED: HPV- 
associated oral epithelial dysplasia; OSCC: oral squamous cell carcinoma; OPC: oropharyngeal squamous cell carcinoma; HRHPV: high-risk human papillomavirus; hpf: high-power field; PCR: polymerase chain reaction; E2BS: E2-binding site; LCR: long control region; qRTPCR: quantitative reverse-transcription polymerase chain reaction; FFPE: formalin-fixed paraffin-embedded; UMSCC: University of Michigan Squamous Cell Carcinoma; cDNA: complementary DNA.

\section{Author contributions}

Conceived and designed the experiments: ABJ, BSS, SK, RAR, SNR, JJ. Performed the experiments: SK, MZ, SJG, JJ. Analyzed the data: SK, PJT, JJ. Contributed to the writing of the manuscript: SK, BSS, RAR, ABJ, PJT, JDS, JJ.

\section{ACKNOWLEDGMENTS}

We would like to acknowledge Ms. Denise Kelley of the Special Procedures Laboratory at the University of Louisville for sectioning tissue from the FFPE sample blocks for laboratory studies.

\section{CONFLICTS OF INTEREST}

All authors have no conflicts of interest.

\section{FUNDING}

This study was funded by anonymous donations for Oral Cancer Research, the James Graham Brown Cancer Center, the Elas U. Pardee Foundation, the School of Dentistry Research Program, and a Commission on Diversity and Racial Equality (CODRE)/Graduate School Diversity Grant, University of Louisville.

\section{REFERENCES}

1. Fakhry C, Westra WH, Li S, Cmelak A, Ridge JA, Pinto H, Forastiere A, Gillison ML. Improved survival of patients with human papillomavirus-positive head and neck squamous cell carcinoma in a prospective clinical trial. J Natl Cancer Inst. 2008; 100:261-9. https://doi.org/10.1093/jnci/djn011.

2. Chen SF, Yu FS, Chang YC, Fu E, Nieh S, Lin YS. Role of human papillomavirus infection in carcinogenesis of oral squamous cell carcinoma with evidences of prognostic association. J Oral Pathol Med. 2012; 41:9-15. https://doi. org/10.1111/j.1600-0714.2011.01046.x.

3. Khanal S, Trainor PJ, Zahin M, Ghim SJ, Joh J, Rai SN, Jenson AB, Shumway BS. Histologic variation in high grade oral epithelial dysplasia when associated with highrisk human papillomavirus. Oral Surgery, Oral Medicine, Oral Pathology and Oral Radiology. 2017; 123:566-85. https://doi.org/10.1016/j.oooo.2017.01.008.
4. McCord C, Xu J, Xu W, Qiu X, McComb RJ, PerezOrdonez B, Bradley G. Association of high-risk human papillomavirus infection with oral epithelial dysplasia. Oral surgery, oral medicine, oral pathology and oral radiology. 2013; 115:541-9.

5. Woo SB, Cashman EC, Lerman MA. Human papillomavirus-associated oral intraepithelial neoplasia. Modern Pathology. 2013; 26:1288-97.

6. Williams VM, Filippova M, Soto U, Duerksen-Hughes PJ. HPV-DNA integration and carcinogenesis: putative roles for inflammation and oxidative stress. Future Virol. 2011; 6:45-57. https://doi.org/10.2217/fvl.10.73.

7. Hopman AH, Smedts F, Dignef W, Ummelen M, Sonke G, Mravunac M, Vooijs GP, Speel EJM, Ramaekers F. Transition of high-grade cervical intraepithelial neoplasia to micro-invasive carcinoma is characterized by integration of HPV 16/18 and numerical chromosome abnormalities. The Journal of pathology. 2004; 202:23-33.

8. Clarke MA, Wentzensen N, Mirabello L, Ghosh A, Wacholder S, Harari A, Lorincz A, Schiffman M, Burk RD. Human papillomavirus DNA methylation as a potential biomarker for cervical cancer. Cancer Epidemiology Biomarkers \& Prevention. 2012; 21:2125-37.

9. Jacquin E, Baraquin A, Ramanah R, Carcopino X, Morel A, Valmary-Degano S, Bravo IG, de Sanjosé S, Riethmuller D, Mougin C. Methylation of Human Papillomavirus Type 16 CpG Sites at E2-Binding Site 1 (E2BS1), E2BS2, and the Sp1-Binding Site in Cervical Cancer Samples as Determined by High-Resolution Melting Analysis-PCR. Journal of clinical microbiology. 2013; 51:3207-15.

10. Tan SH, Leong L, Walker PA, Bernard HU. The human papillomavirus type $16 \mathrm{E} 2$ transcription factor binds with low cooperativity to two flanking sites and represses the E6 promoter through displacement of Sp1 and TFIID. Journal of virology. 1994; 68:6411-20.

11. Thierry F. Transcriptional regulation of the papillomavirus oncogenes by cellular and viral transcription factors in cervical carcinoma. Virology. 2009; 384:375-9.

12. Gupta AK, Kumar M. HPVbase-a knowledgebase of viral integrations, methylation patterns and microRNAs aberrant expression: As potential biomarkers for Human papillomaviruses mediated carcinomas. Sci Rep. 2015; $5: 12522$.

13. Andersson S, Safari H, Mints M, Lewensohn-Fuchs I, Gyllensten U, Johansson B. Type distribution, viral load and integration status of high-risk human papillomaviruses in pre-stages of cervical cancer (CIN). Br J Cancer. 2005; 92:2195-200. https://doi.org/10.1038/sj.bjc.6602648.

14. Badaracco G, Venuti A. Physical status of HPV types 16 and 18 in topographically different areas of genital tumours and in paired tumour-free mucosa. Int J Oncol. 2005; 27:161-7.

15. Cricca M, Morselli-Labate AM, Venturoli S, Ambretti S, Gentilomi GA, Gallinella G, Costa S, Musiani M, Zerbini M. Viral DNA load, physical status and E2/E6 ratio as markers to grade HPV16 positive women for high-grade 
cervical lesions. Gynecol Oncol. 2007; 106:549-57. https:// doi.org/10.1016/j.ygyno.2007.05.004.

16. Hudelist G, Manavi M, Pischinger KI, Watkins-Riedel T, Singer CF, Kubista E, Czerwenka KF. Physical state and expression of HPV DNA in benign and dysplastic cervical tissue: different levels of viral integration are correlated with lesion grade. Gynecol Oncol. 2004; 92:873-80. https:// doi.org/10.1016/j.ygyno.2003.11.035.

17. Li W, Wang W, Si M, Han L, Gao Q, Luo A, Li Y, Lu Y, Wang S, Ma D. The physical state of HPV16 infection and its clinical significance in cancer precursor lesion and cervical carcinoma. J Cancer Res Clin Oncol. 2008; 134:1355-61. https://doi.org/10.1007/s00432-008-0413-3.

18. Wentzensen N, Vinokurova S, von Knebel Doeberitz M. Systematic review of genomic integration sites of human papillomavirus genomes in epithelial dysplasia and invasive cancer of the female lower genital tract. Cancer Res. 2004; 64:3878-84. https://doi.org/10.1158/0008-5472. can-04-0009.

19. Olthof NC, Speel EJM, Kolligs J, Haesevoets A, Henfling M, Ramaekers FC, Preuss SF, Drebber U, Wieland U, Silling S. Comprehensive analysis of HPV16 integration in OSCC reveals no significant impact of physical status on viral oncogene and virally disrupted human gene expression. PLoS One. 2014; 9:e88718.

20. Olthof NC, Huebbers CU, Kolligs J, Henfling M, Ramaekers FC, Cornet I, van Lent-Albrechts JA, Stegmann AP, Silling S, Wieland U, Carey TE, Walline HM, Gollin SM, et al. Viral load, gene expression and mapping of viral integration sites in HPV16-associated HNSCC cell lines. Int J Cancer. 2015; 136:E207-18. https://doi.org/10.1002/ijc.29112.

21. Akagi K, Li J, Broutian TR, Padilla-Nash H, Xiao W, Jiang B, Rocco JW, Teknos TN, Kumar B, Wangsa D. Genomewide analysis of HPV integration in human cancers reveals recurrent, focal genomic instability. Genome research. 2014; 24:185-99.

22. Mellin H, Dahlgren L, Munck-Wikland E, Lindholm J, Rabbani H, Kalantari M, Dalianis T. Human papillomavirus type 16 is episomal and a high viral load may be correlated to better prognosis in tonsillar cancer. Int J Cancer. 2002; 102:152-8. https://doi.org/10.1002/ijc.10669.

23. Hafkamp HC, Speel EJ, Haesevoets A, Bot FJ, Dinjens WN, Ramaekers F, Hopman AH, Manni JJ. A subset of head and neck squamous cell carcinomas exhibits integration of HPV 16/18 DNA and overexpression of p16INK4A and p53 in the absence of mutations in p53 exons 5-8. International journal of cancer. 2003; 107:394-400.

24. Begum S, Cao D, Gillison M, Zahurak M, Westra WH. Tissue distribution of human papillomavirus 16 DNA integration in patients with tonsillar carcinoma. Clinical Cancer Research. 2005; 11:5694-9.

25. Speel EJ. HPV Integration in Head and Neck Squamous Cell Carcinomas: Cause and Consequence. Recent Results Cancer Res. 2017; 206:57-72. https://doi. org/10.1007/978-3-319-43580-0_4.
26. Kim SH, Koo BS, Kang S, Park K, Kim H, Lee KR, Lee MJ, Kim JM, Choi EC, Cho NH. HPV integration begins in the tonsillar crypt and leads to the alteration of p16, EGFR and c-myc during tumor formation. International Journal of Cancer. 2007; 120:1418-25.

27. Lace MJ, Anson JR, Klussmann JP, Wang DH, Smith EM, Haugen TH, Turek LP. Human papillomavirus type 16 (HPV-16) genomes integrated in head and neck cancers and in HPV-16-immortalized human keratinocyte clones express chimeric virus-cell mRNAs similar to those found in cervical cancers. Journal of virology. 2011; 85:1645-54.

28. Parfenov M, Pedamallu CS, Gehlenborg N, Freeman SS, Danilova L, Bristow CA, Lee S, Hadjipanayis AG, Ivanova EV, Wilkerson MD. Characterization of HPV and host genome interactions in primary head and neck cancers. Proceedings of the National Academy of Sciences. 2014; 111:15544-9.

29. Deng Z, Hasegawa M, Kiyuna A, Matayoshi S, Uehara T, Agena S, Yamashita Y, Ogawa K, Maeda H, Suzuki M. Viral load, physical status, and E6/E7 mRNA expression of human papillomavirus in head and neck squamous cell carcinoma. Head Neck. 2013; 35:800-8. https://doi. org/10.1002/hed.23034.

30. Gao G, Johnson SH, Kasperbauer JL, Eckloff BW, Tombers NM, Vasmatzis G, Smith DI. Mate pair sequencing of oropharyngeal squamous cell carcinomas reveals that HPV integration occurs much less frequently than in cervical cancer. J Clin Virol. 2014; 59:195-200. https://doi. org/10.1016/j.jcv.2013.12.006.

31. Koskinen WJ, Chen RW, Leivo I, Makitie A, Back L, Kontio R, Suuronen R, Lindqvist C, Auvinen E, Molijn A, Quint WG, Vaheri A, Aaltonen LM. Prevalence and physical status of human papillomavirus in squamous cell carcinomas of the head and neck. Int J Cancer. 2003; 107:401-6. https://doi.org/10.1002/ijc.11381.

32. Vojtechova Z, Sabol I, Salakova M, Turek L, Grega M, Smahelova J, Vencalek O, Lukesova E, Klozar J, Tachezy $\mathrm{R}$. Analysis of the integration of human papillomaviruses in head and neck tumours in relation to patients' prognosis. Int J Cancer. 2016; 138:386-95. https://doi.org/10.1002/ijc.29712.

33. Elango KJ, Suresh A, Erode EM, Subhadradevi L, Ravindran HK, Iyer SK, Iyer SK, Kuriakose MA. Role of human papilloma virus in oral tongue squamous cell carcinoma. Asian Pac J Cancer Prev. 2011; 12:889-96.

34. Lee SY, Cho NH, Choi EC, Baek SJ, Kim WS, Shin DH, Kim SH. Relevance of human papilloma virus (HPV) infection to carcinogenesis of oral tongue cancer. Int J Oral Maxillofac Surg. 2010; 39:678-83. https://doi. org/10.1016/j.ijom.2010.03.014.

35. Mooren JJ, Gultekin SE, Straetmans JM, Haesevoets A, Peutz-Kootstra CJ, Huebbers CU, Dienes HP, Wieland U, Ramaekers FC, Kremer B, Speel EJ, Klussmann JP. P16(INK4A) immunostaining is a strong indicator for high-risk-HPV-associated oropharyngeal carcinomas and dysplasias, but is unreliable to predict low-risk-HPV-infection 
in head and neck papillomas and laryngeal dysplasias. Int $\mathrm{J}$ Cancer. 2014; 134:2108-17. https://doi.org/10.1002/ijc.28534.

36. Lingen MW, Xiao W, Schmitt A, Jiang B, Pickard R, Kreinbrink P, Perez-Ordonez B, Jordan RC, Gillison ML. Low etiologic fraction for high-risk human papillomavirus in oral cavity squamous cell carcinomas. Oral Oncol. 2013; 49:1-8. https://doi.org/10.1016/j.oraloncology.2012.07.002.

37. Wilson GA, Lechner M, Köferle A, Caren H, Butcher LM, Feber A, Fenton T, Jay A, Boshoff C, Beck S. Integrated virus-host methylome analysis in head and neck squamous cell carcinoma. Epigenetics. 2013; 8:953-61.

38. Park IS, Chang X, Loyo M, Wu G, Chuang A, Kim MS, Chae YK, Lyford-Pike S, Westra WH, Saunders JR. Characterization of the methylation patterns in human papillomavirus type 16 viral DNA in head and neck cancers. Cancer Prevention Research. 2011; 4:207-17.

39. Ramamoorthy S, Liu YT, Luo L, Miyai K, Lu Q, Carethers JM. Detection of multiple human papillomavirus genotypes in anal carcinoma. Infect Agent Cancer. 2010; 5:17.

40. Young RJ, Rischin D, Fisher R, McArthur GA, Fox SB, Peters LJ, Corry J, Lim A, Waldeck K, Solomon B. Relationship between epidermal growth factor receptor status, p16INK4A, and outcome in head and neck squamous cell carcinoma. Cancer Epidemiol Biomarkers Prev. 2011; 20:1230-7.

41. Kang H, Kiess A, Chung CH. Emerging biomarkers in head and neck cancer in the era of genomics. Nat Rev Clin Oncol. 2015; 12:11-26. https://doi.org/10.1038/ nrclinonc.2014.192.

42. Zhang C, Deng Z, Pan X, Uehara T, Suzuki M, Xie M. Effects of Methylation Status of $\mathrm{CpG}$ Sites within the HPV16 Long Control Region on HPV16-Positive Head and Neck Cancer Cells. PloS one. 2015; 10:e0141245.

43. Yang HJ. Aberrant DNA methylation in cervical carcinogenesis. Chin J Cancer. 2013; 32:42-8. https://doi. org/10.5732/cjc.012.10033.

44. Peitsaro P, Johansson B, Syrjänen S. Integrated human papillomavirus type 16 is frequently found in cervical cancer precursors as demonstrated by a novel quantitative real-time PCR technique. Journal of clinical microbiology. 2002; 40:886-91.

45. Reuschenbach M, Huebbers CU, Prigge ES, Bermejo JL, Kalteis MS, Preuss SF, Seuthe IM, Kolligs J, Speel EJ, Olthof N, Kremer B, Wagner S, Klussmann JP, et al. Methylation status of HPV16 E2-binding sites classifies subtypes of HPV-associated oropharyngeal cancers. Cancer. 2015; 121:1966-76. https://doi.org/10.1002/cncr.29315.

46. Giarre M, Caldeira S, Malanchi I, Ciccolini F, Leao MJ, Tommasino M. Induction of $\mathrm{pRb}$ degradation by the human papillomavirus type $16 \mathrm{E} 7$ protein is essential to efficiently overcome p16INK4a-imposed G1 cell cycle Arrest. J Virol. 2001; 75:4705-12. https://doi.org/10.1128/ JVI.75.10.4705-4712.2001.
47. Maiti GP, Mondal P, Mukherjee N, Ghosh A, Ghosh S, Dey S, Chakrabarty J, Roy A, Biswas J, Roychoudhury S, Panda CK. Overexpression of EGFR in head and neck squamous cell carcinoma is associated with inactivation of SH3GL2 and CDC25A genes. PLoS One. 2013; 8:e63440. https://doi. org/10.1371/journal.pone.0063440.

48. Lassen P, Overgaard J, Eriksen JG. Expression of EGFR and HPV-associated p16 in oropharyngeal carcinoma: correlation and influence on prognosis after radiotherapy in the randomized DAHANCA 5 and 7 trials. Radiother Oncol. 2013; 108:489-94. https://doi.org/10.1016/j. radonc.2013.08.036.

49. Zimmermann M, Zouhair A, Azria D, Ozsahin M. The epidermal growth factor receptor (EGFR) in head and neck cancer: its role and treatment implications. Radiat Oncol. 2006; 1:11. https://doi.org/10.1186/1748-717X-1-11.

50. Tang AL, Hauff SJ, Owen JH, Graham MP, Czerwinski MJ, Park JJ, Walline H, Papagerakis S, Stoerker J, McHugh JB, Chepeha DB, Bradford CR, Carey TE, et al. UM-SCC-104: a new human papillomavirus-16-positive cancer stem cellcontaining head and neck squamous cell carcinoma cell line. Head Neck. 2012; 34:1480-91. https://doi.org/10.1002/ hed.21962.

51. Jeon S, Allen-Hoffmann BL, Lambert PF. Integration of human papillomavirus type 16 into the human genome correlates with a selective growth advantage of cells. J Virol. 1995; 69:2989-97.

52. Klaes R, Woerner SM, Ridder R, Wentzensen N, Duerst M, Schneider A, Lotz B, Melsheimer P, von Knebel Doeberitz $\mathrm{M}$. Detection of high-risk cervical intraepithelial neoplasia and cervical cancer by amplification of transcripts derived from integrated papillomavirus oncogenes. Cancer Res. 1999; 59:6132-6.

53. Cheung JL, Cheung TH, Yu MY, Chan PK. Virological characteristics of cervical cancers carrying pure episomal form of HPV16 genome. Gynecol Oncol. 2013; 131:374-9. https://doi.org/10.1016/j.ygyno.2013.08.026.

54. Mazumder Indra D, Singh RK, Mitra S, Dutta S, Chakraborty C, Basu PS, Mondal RK, Roychoudhury S, Panda CK. Genetic and epigenetic changes of HPV16 in cervical cancer differentially regulate E6/E7 expression and associate with disease progression. Gynecol Oncol. 2011; 123:597-604. https://doi.org/10.1016/j.ygyno.2011.08.004.

55. Chaiwongkot A, Vinokurova S, Pientong C, Ekalaksananan T, Kongyingyoes B, Kleebkaow P, Chumworathayi B, Patarapadungkit N, Reuschenbach M, von Knebel Doeberitz M. Differential methylation of E2 binding sites in episomal and integrated HPV 16 genomes in preinvasive and invasive cervical lesions. International Journal of Cancer. 2013; 132:2087-94.

56. Ghosh DD, Bhattacharjee B, Sen S, Premi L, Mukhopadhyay I, Chowdhury RR, Roy S, Sengupta S. Some novel insights on HPV16 related cervical cancer pathogenesis based on analyses of LCR methylation, 
viral load, E7 and E2/E4 expressions. PLoS One. 2012; 7:e44678.

57. Balderas-Loaeza A, Anaya-Saavedra G, Ramirez-Amador VA, Guido-Jimenez MC, Kalantari M, Calleja-Macias IE, Bernard HU, Garcia-Carranca A. Human papillomavirus-16 DNA methylation patterns support a causal association of the virus with oral squamous cell carcinomas. Int J Cancer. 2007; 120:2165-9. https://doi.org/10.1002/ijc.22563.

58. Arias-Pulido H, Peyton CL, Joste NE, Vargas H, Wheeler CM. Human papillomavirus type 16 integration in cervical carcinoma in situ and in invasive cervical cancer. J Clin Microbiol. 2006; 44:1755-62. https://doi.org/10.1128/ jcm.44.5.1755-1762.2006.

59. Sano D, Oridate N. The molecular mechanism of human papillomavirus-induced carcinogenesis in head and neck squamous cell carcinoma. Int J Clin Oncol. 2016; 21:81926. https://doi.org/10.1007/s10147-016-1005-x.

60. Zhao M, Sano D, Pickering CR, Jasser SA, Henderson YC, Clayman GL, Sturgis EM, Ow TJ, Lotan R, Carey
TE, Sacks PG, Grandis JR, Sidransky D, et al. Assembly and initial characterization of a panel of 85 genomically validated cell lines from diverse head and neck tumor sites. Clin Cancer Res. 2011; 17:7248-64. https://doi. org/10.1158/1078-0432.ccr-11-0690.

61. Khanal S, Cole ET, Joh J, Ghim SJ, Jenson AB, Rai SN, Trainor PJ, Shumway BS. Human papillomavirus detection in histologic samples of multifocal epithelial hyperplasia: a novel demographic presentation. Oral Surg Oral Med Oral Pathol Oral Radiol. 2015; 120:733-43. https://doi. org/10.1016/j.oooo.2015.07.035.

62. Livak K, Schmittgen T. Analysis of relative gene expression data using real-time quantitative PCR and the $2-\Delta \Delta \mathrm{CT}$ Method. Methods. 2001; 25:402-408.

63. Holm S. A simple sequentially rejective multiple test procedure. Scandinavian Journal of Statistics. 1979; 6:65-70. 